\title{
ELECTROANTENNOGRAPHY IN THE STUDY OF TWO STINGLESS BEE SPECIES (HYMENOPTERA: MELIPONINI**
}

\author{
PATRICIO, E. F. L. R. A., ${ }^{1}$ CRUZ-LÓPEZ, L. ${ }^{2}$ and MORGAN, E. D. ${ }^{3}$ \\ ${ }^{1}$ Laboratório de Abelhas, Departamento de Ecologia Geral, Instituto de Biociências, Universidade de São Paulo, \\ CEP 05508-900, São Paulo, SP, Brazil \\ ${ }^{2}$ El Colegio de La Frontera Sur, Tapachula, CEP 30700, Chiapas, Mexico \\ ${ }^{3}$ Chemical Ecology Group, Lennard-Jones Laboratory, School of Chemistry and Physics, \\ Keele University, Staffs, ST5 5BG, England \\ Correspondence to: Eda Flávia L. R. A. Patrício, Laboratório de Abelhas, Departamento de Ecologia Geral, \\ Instituto de Biociências, Universidade de São Paulo, Rua do Matão, Trav. 14, 321, CEP 05508-900, \\ São Paulo, SP, Brazil, e-mail: edaflap@usp.br \\ Received September 10, 2003 - Accepted January 22, 2004 - Distributed November 30, 2004
}

(With 1 figure)

\begin{abstract}
The first recorded electroantennographic preliminary studies on stingless bees have been performed using two species of Frieseomelitta from Brazil. Experiments with $F$. silvestrii and $F$. varia showed that antennae respond to hexane extracts of heads and abdomens of both species and posterior tibia of F. silvestrii (which carry plant resin), as well as to the pure compounds 2-heptanol and 2-nonanol, which occur in the mandibular glands of both species, and to the terpenes $\alpha$-cubebene, humulene, and $\beta$-caryophyllene found on their tibia and in the cerumen of their nests.
\end{abstract}

Key words: Frieseomelitta, antennal response, exocrine glands, propolis, odor.

\section{RESUMO}

\section{Eletroantenografia no estudo de abelhas sem ferrão (Hymenoptera: Meliponini)}

Relatam-se aqui os resultados preliminares de estudos eletroantenográficos realizados com duas espécies de Frieseomellita brasileira. Os experimentos com $F$. silvestrii e $F$. varia mostraram que as antenas respondem aos extratos obtidos com hexano das cabeças e dos abdômens das duas espécies e da tíbia posterior de F. silvestrii (que transporta resinas coletadas de plantas). Respondem também aos compostos puros, 2 -heptanol e 2-nonanol, e aos terpenos, $\alpha$-cubebeno, humuleno e $\beta$-cariofileno, encontrados nas tíbias e no cerume de seus próprios ninhos.

Palavras-chave: Fieseomelitta, resposta antenal, glândulas exócrinas, própolis, odor.

\section{INTRODUCTION}

Stingless bees of the hymenopteran group Meliponini display complex communication patterns, and much of that communication must stem from glandular secretions. The study of pheromones in stingless bees is still in its infancy. The most important exocrine glands in stingless bees that might be implicated in pheromone production include, in the head, the mandibular glands; in the thorax, the thoracic salivary glands; and in the abdomen, the Dufour gland and epidermal glands.
Mandibular gland secretion of stingless bees has been more extensively studied because, among them, it appears to play an important part in chemical communication (Kerr et al., 1963). Engels and Francke have together analyzed the cephalic secretions of a large number of species and made relations to age and development (Engels et al., 1993, 1997; Francke et al., 2000; and earlier papers). We have only recently made the first chemical studies of the Dufour glands of stingless bees (Cruz-López et al., 2001; Patricio et al., 2003). Some early studies with pure chemicals were made to study their effects on 
the behaviour of stingless bees (Weaver et al., 1975; Smith \& Roubik, 1983), but the subject has progressed slowly.

The electroantennograph technique (EAG) measures the summation of receptor potentials from responding cells in insect antennae (Kaissling, 1971). It has been much used to identify active pheromone substances in a mixture of volatile compounds extracted from insects, and has played an important part in the identification of lepidopteran pheromones. As for honeybees, it is known that they detect odours by using olfactory receptor cells in their antennae (Lacher, 1964; Vareschi, 1971; Williams et al., 1982), and no doubt stingless bees do too.

The recognition of active compounds in EAG studies can be a short-cut in identifying compounds recognized by antennal receptors that may be used in pheromone communication. Until our present work there have been no EAG studies on any stingless bees. We have analyzed the mandibular glands (Cruz-López et al., 2002), the hind tibia that carry plant resin and nest propolis (Patricio et al., 2002), and the Dufour glands (Patricio et al., 2003) of three species of Frieseomelitta. They therefore provided a good starting point from which to initiate EAG studies. In our experience, while EAG with Lepidoptera is relatively easy and yields large potential responses, with ants it is very difficult and gives much lower potentials (Wadhams \& Morgan, unpublished). We give here a full account of the first studies by EAG with stingless bees, using two species of Frieseomelitta from Brazil, that show that this approach to studying communication chemicals is practical and promising. A brief report on our study of the chemicals from the heads of Frieseomelitta has already been published (Cruz-López et al., 2002).

\section{METHODS AND MATERIALS}

Insects. Workers of F. varia Lepeletier 1836 and $F$. silvestrii Ihering 1912 were provided from the collection of Professor Paulo Nogueira Neto and from the Laboratório de Abelhas, Instituto de Biociências, Universidade de São Paulo, Brazil. F. varia were collected at Ribeirão Preto in northern São Paulo State. F. silvestrii came originally from Luiziania in Goiás State, near Brasília. Groups of about 50 worker bees with brood cells, honey, and pollen pots were used, and supplied with water.
Extracts were prepared by placing the body parts of worker bees (heads, abdomens, and hind legs), and of pieces of cerumen taken from their nest, in small glass tubes containing hexane $(0.5 \mathrm{ml})$, and allowing them to stand for $30 \mathrm{~min}$. Pure compounds (geranylfarnesol, $\alpha$-cubebene, humulene, and $\beta$ caryophyllene, $10 \mathrm{mg}$ each) were dissolved in hexane (10 ml).

Electroantennography was performed using excised antennae of $F$. silvestrii and $F$. varia workers. Electrodes were drawn from $1 \mathrm{~mm}$ i.d. borosilicate tubes to produced capillaries with a taper length of $0.5 \mathrm{~cm}$ with the tips filled with saline solution prepared according to Maddrell (1969) but omitting the sucrose. An antenna was placed between two electrodes, one inserted at the base of the antenna and serving as the reference electrode, and another, the recording electrode, placed at the tip of the antenna. In all, 20 antennae were used for $F$. silvestrii and five for $F$. varia.

For the electroantennogram, hexane solution $(10 \mathrm{ml})$ was impregnated onto a strip of filter paper, $15 \times 1.5 \mathrm{~mm}$, which was then placed in a disposable glass pipette. While air was continuously blown over the antenna, the pipette tip containing the strip of filter paper was inserted in a hole at the end of the tube carrying the air stream, thus delivering vapor from an unknown quantity (equivalent to one worker head, abdomen, or tibia) of extract or from $10 \mathrm{mg}$ of one of the pure compounds. The vapor was puffed from the filter paper with a solenoid-controlled nitrogen stream $(3 \mathrm{ml} / \mathrm{sec})$. The signals, amplified with an AC coupled amplifier, were displayed on an oscilloscope (Devices 3131, Dynamic Electronics Limited). A permanent trace was obtained with a Devices M2 pen recorder. Only two replicates of the experiment were made with $F$. varia because only a limited number of live bees were available. Results of $F$. silvestrii were analyzed using student's $t$ test. No statistical test was performed with the $F$. varia results because of the small number of replicates.

\section{RESULTS}

Satisfactory electroantennography experiments were conducted with $F$. silvestrii, but by the time the experiments were performed with $F$. varia, only two good replicates were obtained. Table 1 shows the EAG responses of $F$. silvestrii to abdominal, head, and hind 
leg extracts in hexane. A typical electroantennogram is shown in Fig. 1. Also tested were two important components of the mandibular secretion of $F$. silvestrii: 2-nonanol and 2-undecanol; three volatile terpenes from the posterior tibia: $\alpha$-cubebene, humulene, and $\beta$-caryophyllene; and geranylfarnesol, a component of the Dufour gland (Patricio et al., 2003). All the extracts and synthetic compounds except geranylfarnesol gave significant EAG responses. One of the sesquiterpenes from the tibia, $\alpha$-Cubebene, (Patricio et al., 2002) gave a particularly strong response (Table 1 ), although there was less of this compound found on the tibia of $F$. silvestrii (Patricio et al., 2002) than $\beta$-caryophyllene (which gave a weaker response). However, from the analytical conditions used in the analysis of resin on the tibia (Patricio et al., 2002) it was not possible to know which enantiomer of $\beta$ caryophyllene was present on the tibia, since commercially available (-)- $\beta$-caryophyllene was used. The limited experiment on $F$. varia nevertheless gave strong responses to solvent extracts of abdomen, head, and cerumen (Table 1). Nonanal and 2-undecanol were the important mandibular compounds to test with $F$. varia. Shortage of live bees limited the experiment on $F$. varia; nevertheless, responses to solvent extracts of head, abdomen, cerumen, and the pure compounds nonanal and 2-nonanol were all strong, and only that to 2-undecanol was comparatively weak (Table 1 ).

\section{DISCUSSION}

The electroantennographic (EAG) technique has been used to determine which of the compounds present in a mixture of volatiles can stimulate olfactory receptors. No physiological information of this type was available for stingless bees, therefore preliminary EAG studies were undertaken using the antennae of $F$. varia and $F$. silvestrii. Head, abdominal, and tibial extracts of $F$. silvestrii all gave equally strong antennal responses. The responses of $F$. varia antennae to body extracts were very similar to those obtained with $F$. silvestrii. Strongest responses of the pure compounds were given by $\alpha$-Cubebene and 2-nonanol. It is noteworthy that in both species 2-nonanol gave stronger responses than 2-undecanol. Further planned experiments that included extracts of individual dissected glands were cut short by the decline of the colonies. Geranylfarnesol is only a trace component in the Dufour glands of $F$. silvestrii but is the major substance in the closely related $F$. silvestrii languida (Patricio et al., 2003).

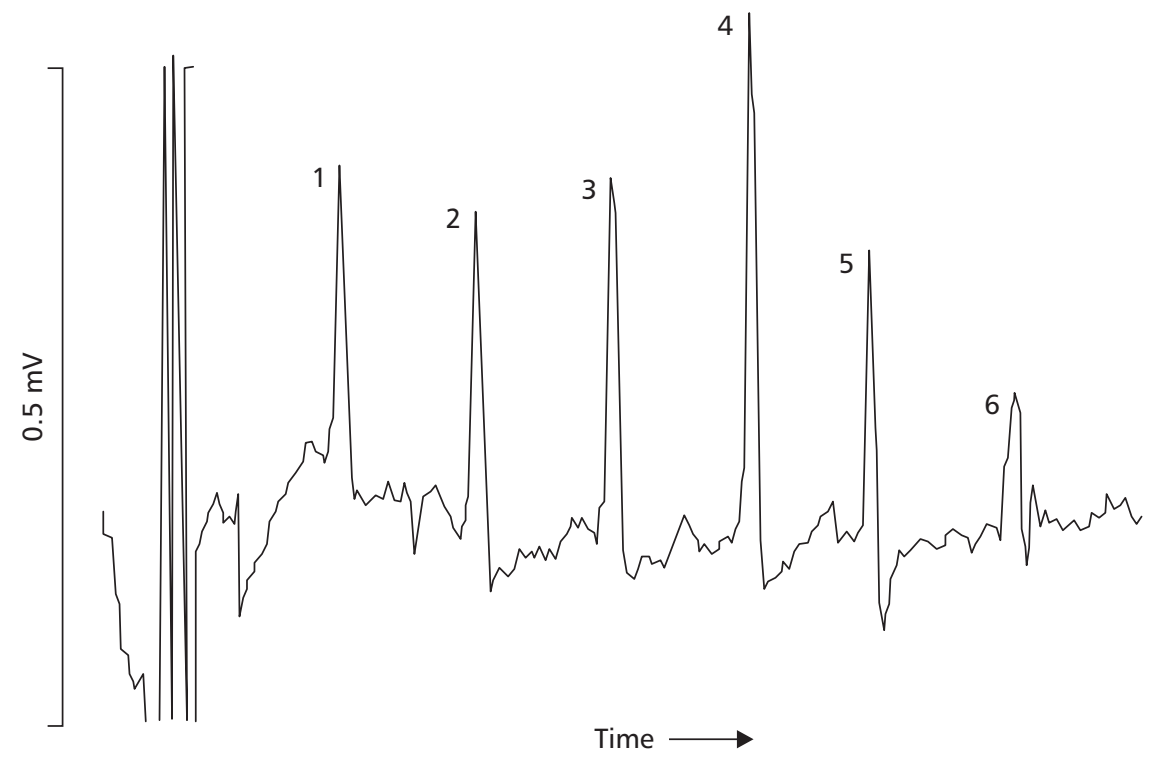

Fig. 1 - An example of an electroantennogram taken from the antenna of a worker of Frieseomelitta silvestriii. Peaks were obtained after applying the following extracts or pure chemicals: 1 , head extract; 2 , tibial extract; 3 , abdominal extract; 4 , cerum extract; 5, 2-nonanol; 6, 2-undecanol. 
TABLE 1

Mean and standard deviation of the EAG responses of the Frieseomelitta silvestrii and $F$. varia antennae to some body extracts and synthetic samples of compounds identified in their exocrine glands.

\begin{tabular}{|c|c|c|c|c|c|}
\hline \multirow[b]{2}{*}{ Stimulus** } & \multicolumn{2}{|c|}{ F. silverstrii } & \multicolumn{3}{|c|}{$F$. varia } \\
\hline & $\begin{array}{c}\text { Response } \\
(\mathrm{mV} \pm \mathrm{SD})\end{array}$ & Replicates & $\begin{array}{l}\text { Rest } \\
(\mathrm{mV}\end{array}$ & $\begin{array}{l}\text { ponse } \\
\pm \text { SD) }\end{array}$ & Replicates \\
\hline Head extract & $0.095 \pm 0.013^{*}$ & 15 & $0.105=$ & \pm 0.035 & 2 \\
\hline Hind legs extract & $0.101 \pm 0.020^{*}$ & 8 & & - & - \\
\hline Abdominal extract & $0.12 \pm 0.025 *$ & 5 & 0.100 & \pm 0.010 & 2 \\
\hline Cerumen extract & - & - & 0.055 & \pm 0.055 & 2 \\
\hline Nonanal & - & - & 0.027 & \pm 0.000 & 2 \\
\hline 2-Nonanol & $0.109 \pm 0.016^{*}$ & 7 & 0.025 & \pm 0.005 & 2 \\
\hline 2-Undecanol & $0.063 \pm 0.011 *$ & 7 & 0.010 & \pm 0.010 & 2 \\
\hline Geranylfarnesol & $0.012 \pm 0.004 \mathrm{NS}$ & 5 & & - & - \\
\hline$\alpha$-Cubebene & $0.16 \pm 0.014^{*}$ & 16 & & - & - \\
\hline Humulene & $0.069 \pm 0.011^{*}$ & 9 & & - & - \\
\hline$(-)-\beta$-Caryophyllene $\dagger$ & $0.062 \pm 0.009^{*}$ & 8 & & - & - \\
\hline
\end{tabular}

* Significantly different from control at $\mathrm{p}=0.001, \mathrm{NS}=$ not significantly different from control at $\mathrm{p}=0.001$ (control hexane, $10 \mu \mathrm{l})$.

**Appling $10 \mu \mathrm{l}$ of the hexane extract (see Methods and Materials) and $10 \mu \mathrm{l}$ of a solution $\left(1 \mathrm{~g} \mathrm{~L}^{-1}\right)$ of pure compounds.

$\dagger$ The absolute configuration of the $\beta$-caryophyllene on the tibia (Patricio et al., 2002) has not been determined.

It was available for tests, but its poor response, not significantly different from that of the hexane control, could be due to low volatility because of its relatively high molecular mass (358 mass units). We have reported earlier on the plant resin substances found on the hind tibia of these species (Patricio et al., 2002) and we have tested three of the substances found there both on $F$. silvestrii and an extract of the cerumen from the nest of $F$. varia. The results show that individual substances and mixtures of compounds present in the abdomen, cerumen, and on the tibia of Frieseomelitta bees can elicit olfactory responses in bee antennae. This is consistent with the hypothesis that such volatiles can elicit behavioral responses. What kind of behavior these materials induce has yet to be discovered.

Our brief study shows that EAG can provide a route to learning more about chemical communication in stingless bees. From the mixtures of chemicals found in glands, the EAG can select substances that show a positive response and deserve further study in behavioral experiments. The relatively simple mixture of substances in F. silvestrii makes it a suitable candidate for behavioral studies with synthetic compounds.

Acknowledgements - We thank Professor Paulo Nogueira Neto, Universidade de São Paulo for the colonies of $F$. varia and $F$. silvestrii; Prof. J. S. Moure (Universidade Federal do Paraná, Curitiba), for identifying the species; and especially Prof. L. J. Wadhams at Rothamsted for the use of his EAG equipment. This work was partly supported by CONACYT México, through a studentship to LCL and partly through the research network Social Evolution of seven European universities financed by the European Commission via the Training and Mobility of Researchers (TMR) program (Contract ERBFMRXCT 960072). We thank C. Mansfield, International Flavours and Fragrances Ltd. for the sample of geranylfarnesol.

\section{REFERENCES}

CRUZ-LÓPEZ, L., PATRICIO, E. F. L. R. A. \& MORGAN, E. D., 2001, Secretions of stingless bees: the Dufour gland of Nannotrigona testaceicornis. J. Chem. Ecol., 27: 69-80.

CRUZ-LÓPEZ, L., PATRICIO, E. F. L. R. A., MAILE, R. \& MORGAN, E. D., 2002, Secretions of stingless bees: cephalic secretions of two Frieseoelitta species. J. Insect Physiol., 48: 453-458. 
ENGELS, E., ENGELS, W., LÜBKE, G., SCHRODER, W. \& FRANCKE, W., 1993, Age-related patterns of volatile cephalic constituents in queens of the neotropical stingless bee Scaptotrigona postica Latr. (Hymenoptera, Apidae). Apidologie, 24: 539-548.

ENGELS, W., ENGELS, E. \& FRANCKE, W., 1997, Ontogeny of cephalic volatile patterns in queens and mating biology of the neotropical stingless bee, Scaptotrigona postica. Invertebr. Reprod. Dev., 31: 251-256.

FRANCKE, W., LUBKE, G., SCHRODER, W., RECKZIEGEL, A., IMPERATRIZ-FONSECA, V., KLEINERT, A., ENGELS, E., HARTFELDER, K., RADTKE, R. \& ENGELS, W., 2000, Identification of oxygen containing volatiles in cephalic secretions of workers of Brazilian stingless bees. J. Brazil Chem. Soc., 11: 562-571.

KAISSLING, K. E., 1971, Insect olfaction, pp. 351-431. In: L. M. Beidler (ed.), Chemical Senses, 4., Part 1, In the series Handbook of Sensory Physiology, Springer-Verlag, Berlin.

KERR, W. E., FERREIRA, E. A. \& DE MATTOS, N. S., 1963, Communication among stingless bees; additional data. $J$. New York Entomol. Soc., 71: 80-89.

LACHER, V., 1964, Electrophysiologische Untersuchungen an einzelnen Rezeptoren für Geruch. Kohlendioxyd, Luftfeuchtigkeit und Temperatur auf den Antennen der Arbeitsbiene und der Drohne. Z. Vergl. Physiol., 48: $587-$ 623.
MADDRELL, S. H. P., 1969, Secretion by the Malpighian tubules of Rhodnius. The movement of ions and water. $J$. Exper. Biol., 51: 71-79.

PATRICIO, E. F. L. R. A., CRUZ-LÓPEZ, L., MAILE, R., TENTSCHERT, J., JONES, G. R. \& MORGAN, E. D., 2002, The propolis of stingless bees: terpenes from the tibia of three Frieseomelitta species. J. Insect Physiol., 48: 249-254.

PATRICIO, E. F. L. R. A., CRUZ LÓPEZ, L. \& MORGAN, E. D., 2003. Secretions of stingless bees: the Dufour glands of some Frieseoelitta species. Apidologie, 34(4): 359-365.

SMITH, B. H. \& ROUBIK, D. W., 1983, Mandibular glands of stingless bees (Hymenoptera: Apidae): Chemical analysis of their contents and biological function in two species of Melipona. J. Chem. Ecol., 9: 1465-1472.

VARESCHI, E., 1971, Duftunterscheidung bei der HonigbieneEinzell-Ableitungen und Verhaltensreaktionen. Z. Vergl. Physiol., 75: 143-173.

WEAVER, N., WEAVER, E. C. \& CLARKE, E. T., 1975, Reactions of five species of stingless bees to some volatile chemicals and to other species of bees. J. Insect Physiol., 21: 479-494.

WILLIAMS, I. H., PICKETT, J. A. \& MARTIN, A. P., 1982, Nasonov pheromone of the honeybee Apis mellifera $\mathrm{L}$. (Hymenoptera: Apidae) IV Comparative electroantennogram response. J. Chem. Ecol., 8: 567-574.

*This paper is published in honor of Father J. S. Moure, D. D., a professor at the Federal University of Paraná. An entomologist, he has dedicated his life to the study of biology, particularly bee systematics. It was he who identified the specimens studied here. At over 90 years of age, he continues on as a tireless researcher, readily responding to requests for guidance and suggestions from fellow scientists working within his professional area. For beginning and veteran scientists alike, his example will endure. With gratitude, we salute him.

*Este artigo é publicado em homenagem ao cientista Pe. J. S. Moure, D. D. Entomólogo, Professor da Universidade Federal do Paraná, que tem dedicado sua vida à pesquisa da biologia e sistemática de abelhas. Devemos a ele a identificação dos exemplares estudados. O Pe. Moure, embora com mais de 90 anos de idade, é um incansável pesquisador, pronto a atender a solicitações e a ajudar a solucionar problemas que lhe são apresentados. É um exemplo para novos (e velhos) cientistas. A ele, nossa homenagem e gratidão. 